\title{
Stem cell factor and c-kit gene expression and protein localization in the sheep ovary during fetal development
}

\author{
D. J. Tisdall2, A. E. Fidler ${ }^{1}$, P.Smith ${ }^{1}$, L. D. Quirke ${ }^{1}$, V. C. Stent ${ }^{1}$, D. A. Heath ${ }^{1}$ and K. P. McNatty ${ }^{1 *}$ \\ ${ }^{1}$ AgResearch, Wallaceville Animal Research Centre, PO Box 40063, Upper Hutt, New Zealand; and ${ }^{2} H R C$ Virus Research Unit, \\ Department of Microbiology, University of Otago, PO Box 56, Dunedin, New Zealand
}

\begin{abstract}
The aim of this study was to investigate stem cell factor and c-kit gene expression and protein localization in the mesonephros and ovary of sheep fetuses at different days of gestation, using RNA in situ hybridization and immunohistochemical procedures. At days 24 and 26 of gestation, stem cell factor mRNA and protein were present in cells throughout the developing gonad and mesonephros. From day 28 to day 40 of gestation, stem cell factor mRNA and protein became increasingly localized to the cortical region of the ovary, where most germ cells were present as actively proliferating oogonia. From day 40 to day 90 of gestation, stem cell factor $\mathrm{mRNA}$ and protein localization were confined mainly to the ovarian cortex. Moreover, within the cortical region, stem cell factor mRNA was low or absent where follicles were first forming and highest in the outer ovarian cortex, where germ cells were undergoing mitosis or the early stages of meiosis. In contrast, stem cell factor protein was present in newly forming follicles, as well as in mitotic and meiotic germ cells, which is consistent with the presence of both membrane-bound and soluble forms of this ligand. However, by day 90 of gestation, both stem cell factor mRNA and protein were observed in the granulosa cells of most $(>90 \%)$ primordial follicles. C-kit mRNA and protein were observed from day 24 of gestation in both germ cells and somatic cells but, with increasing gestational age, preferentially in germ cells (for example, pre-meiotic germ cells and both isolated oocytes and follicle-enclosed oocytes). C-kit protein, but not mRNA, was also observed in germ cells that were undergoing meiosis. The results indicate that the cells containing stem cell factor mRNA within the ovary up to day 90 of gestation originated from the gonadal blastema and from cells that migrated from the mesonephros before day 28 of gestation. Since stem cell factor mRNA was absent in both mesonephric cells migrating after day 28 of gestation and in regions where follicles were first forming, it is suggested that these later migrating mesonephric cells are the progenitors of the granulosa cells in the first forming follicles. In conclusion, during follicle formation, c-kit mRNA is localized to germ cells whereas c-kit, together with stem cell factor protein, is localized to both germ cells and somatic cells, consistent with the hypothesis that the presence of this receptor-ligand pair is essential to prevent apoptosis.
\end{abstract}

\section{Introduction}

The chemotactic movement of cells along gradients of morphogens is believed to play a central role in the development of multicellular organisms (Neumann and Cohen, 1997). An intriguing example of such directional cell migration occurs in the formation of the vertebrate gonad, during which somatic and germ cells migrate into and colonize the developing gonad (Zamboni et al., 1979; Byskov, 1986). In sheep, the mesonephros, especially the giant glomerulus, makes a major contribution to the developing gonads (Davies and Davies, 1950; Zamboni et al., 1979; Zamboni and Upadhyay, 1982). It is proposed that the granulosa cells are derived from the rete ovarii, which are

*Correspondence.

Received 10 August 1998. themselves derived from the mesonephros, with no obvious contribution from the ovarian surface epithelial cells (Zamboni et al., 1979; McNatty et al., 1995). Regression of the mesonephros from day 24 to day 26 of gestation is accompanied by the mobilization and migration of the mesonephric glomerular and tubular cells, which first colonize the early, sexually indifferent, gonads and later, after sexual differentiation (that is, at day 32 of gestation), the differentiated ovaries (Zamboni et al., 1979). Although regression of the giant glomerulus in sheep fetuses is complete by day 45 of gestation, mesonephric cells continue to migrate to the ovaries until about day 58 of gestation (Zamboni et al., 1979). Within the ovary, the invading mesonephric cells become closely associated with the germ cells that have themselves migrated into the developing gonad from the yolk sac (Eddy et al., 1981). Zamboni et al. 
(1979) described two stages in the migration process from the glomerulus, a 'non-organized' phase at days 24-29 of gestation, during which mesonephric mesangial cells were the predominant class of migrating cells and an 'organized' phase at days 34-58 of gestation, during which migration of a solid cell mass of glomerular (parietal and visceral) and tubular epithelial cells occurs. Cells migrating during both the 'non-organized' and the 'organized' phases contribute to the formation of the ovarian rete (Byskov, 1986). Moreover, evidence from histological and in situ hybridization studies indicates that the ovarian rete cells go on to form the ovarian granulosa cells (Byskov, 1986; Braw-Tal et al., 1994; Tisdall et al., 1994).

Molecular characterization of mutant mouse alleles associated with an aberrant germ cell migration phenotype led to the realization that the ligand-receptor pair, stem cell factor $(\mathrm{SCF})-\mathrm{c}-\mathrm{kit}$, plays a central role in germ cell migration to, and colonization of, the developing genital ridge (Fleischman, 1993). Studies in vitro indicate that this signalling pathway is involved in the proliferation, survival and migration of germ cells and other stem cell lineages (Packer et al., 1994; Orth et al., 1997). Furthermore, in situ hybridization studies indicate the presence of gradients of SCF gene expression which may play a role in the directional migration of germ cells (Keshet et al., 1991). Ovine SCF and ckit cDNA clones have been isolated (Clark et al., 1996; Tisdall et al., 1996; Tisdall et al., 1997) and the genes were found to be expressed in the fetal ovary during the period when follicular growth commences (days 90-135 of gestation). During late gestation, SCF gene expression was observed in granulosa cells at all stages of follicular growth, including primordial follicles. SCF was also observed in the rete ovarii, surface epithelium and in some sub-epithelial cells (Tisdall et al., 1997). In contrast, c-kit gene expression was observed in isolated oocytes and in follicle-enclosed oocytes at all stages of follicular growth. While it is presumed that the cortical epithelium is derived from the coelomic epithelium of the genital ridge, the origin of the SCF-expressing rete and subepithelial cells remains obscure. Moreover, it is not clear whether c-kit expression remains exclusive to germ cells throughout gonadal formation.

The expression of the SCF and c-kit genes was examined, together with the distribution of the corresponding proteins during female gonadal development from the early formation of the sexually indeterminant genital ridge (days 24-30 of gestation) through the periods corresponding to sexual differentiation (days $30-40$ of gestation), meiosis of germ cells (day 55 of gestation) and follicle formation (days 75-90 of gestation), to gain insights into the origins of the cells contributing to the formation of the ovary including the ovarian follicles.

\section{Materials and Methods}

\section{Animals and collection of tissue samples}

All experiments involving animals were conducted after approval was granted by the Animal Ethics Committee at Wallaceville Animal Research Centre and in accordance with the 1987 Animal Protection (Codes of Ethical Conduct) Regulations of New Zealand.

Female sheep fetuses were recovered at days $24,26,28,30$, $35,40,55,75$ and 90 of gestation from Romney ewes (term $=$ day 147 of gestation). The fetuses were the result of matings of Romney ewes that had been superovulated using pregnant mares' serum gonadotrophin (PMSG; Folligon: Intervet, Lane Cove, NSW) and Ovagen (Immuno-Chemical Products Ltd, Auckland) as described by Smith et al. (1993). Four or five days after mating, the embryos were recovered and transferred into oestrous-synchronized recipient ewes (three embryos per ewe using a laparoscopic technique) (see Smith et al., 1993). The purpose of the embryo transfer procedures was to maximize the number of fetuses from the smallest possible number of recipient ewes that needed to be slaughtered. Fetuses were recovered after a barbiturate overdose (Euthatal; approximately $20 \mathrm{ml} \mathrm{i.v.} \mathrm{of} 500 \mathrm{mg} \mathrm{ml}^{-1}$ ) was given to their dam. The fetuses or dissected fetal ovaries or mesonephroi were fixed in $4 \%(\mathrm{w} / \mathrm{v})$ paraformaldehyde in $0.1 \mathrm{~mol} \mathrm{PBS} \mathrm{I}^{-1}$ and embedded in paraffin wax.

\section{Sexing of fetuses}

The sex of fetuses recovered before day 35 of gestation was determined by PCR from tissue sections (Sarkar et al., 1993) using SRY gene-specific primers (Payen and Cotinot, 1994). Briefly, paraffin wax-embedded tissue sections $(6 \mu \mathrm{m})$ were incubated for $2 \mathrm{~h}$ at $55^{\circ} \mathrm{C}$ in $10 \mathrm{mmol}$ Tris $-\mathrm{HCl} \mathrm{l}^{-1}(\mathrm{pH} \mathrm{7.5),}$ $50 \mathrm{mmol} \mathrm{KCl}^{-1}, 2.5 \mathrm{mmol} \mathrm{MgCl}_{2} \mathrm{l}^{-1}, 0.45 \%$ (v/v) Tween 20 and proteinase $\mathrm{K}\left(0.5 \mathrm{mg} \mathrm{ml}^{-1}\right.$; Boehringer Mannheim, Aukland). Aliquots $(10 \mu \mathrm{l})$ of the tissue extract were used as templates for the amplification of sheep SRY gene sequences using 2.5 U Taq DNA polymerase (Boehringer Mannheim) in a total volume of $50 \mu \mathrm{l}$ containing $20 \mathrm{pmol}$ of forward (5'-CATTGTGTGGTCTCGTGAACG-3') and reverse (5'-GTCTCGGTGTATAGCTAGTAG-3') primers and the manufacturers' recommended buffer. PCR was conducted using a thermal cycler (Perkin-Elmer Cetus Corporation, Norwalk, CT) with the following reaction conditions: one cycle of $3 \mathrm{~min}, 95^{\circ} \mathrm{C}$; $3 \mathrm{~min}, 60^{\circ} \mathrm{C} ; 5 \mathrm{~min}, 72^{\circ} \mathrm{C} ; 35$ cycles $30 \mathrm{~s}, 95^{\circ} \mathrm{C} ; 30 \mathrm{~s}, 62^{\circ} \mathrm{C}$; $2 \mathrm{~min}, 72^{\circ} \mathrm{C}$; and a final extension of $10 \mathrm{~min}, 72^{\circ} \mathrm{C}$. The amplification product ( $166 \mathrm{bp}$ ) was visualized in an ethidium bromide stained 2\% agarose gel (NuSieve GTG, FMC Bioproducts, Rockland, ME).

\section{In situ hybridization}

The in situ hybridization protocol used in the present study was described by Tisdall et al. (1994). Single stranded sense and antisense RNA probes ([ $\left.{ }^{33} \mathrm{P}\right]$ UTP label) were synthesized by means of an in vitro transcription kit (Riboprobe ${ }^{(1)}$ Gemini system; Promega, Madison, WI) from a 822 bp ovine SCF cDNA sequence (Tisdall et al., 1997) and a 422 bp ovine c-kit cDNA sequence (Clark et al., 1996) cloned into pGem $4 Z$ and pGem3Z (Promega), respectively. For each probe, at least two sections from three to five different fetuses were examined for each age. Paraformaldehyde-fixed tissue 
sections $(4-6 \mu \mathrm{m})$ were cut and transferred to microscope slides coated with 3-aminopropyltriethoxysilane (Aldrich Chemical Company, Milwaukee, WI). Slides were immersed in three changes of xylene (10 min each), and then hydrated by immersing in $100 \%$ ethanol ( $5 \mathrm{~min} \times 2), 95 \%$ ethanol ( $5 \mathrm{~min})$, $70 \%$ ethanol $(5 \mathrm{~min})$ and water $(5 \mathrm{~min})$. Sections were immersed in $0.2 \mathrm{~mol} \mathrm{HCl}^{-1}$ for $20 \mathrm{~min}$ at room temperature (RT) and washed in $2 \times \mathrm{SSC}$ for $30 \mathrm{~min}$. Proteinase $\mathrm{K}(2 \mu \mathrm{g}$ $\mathrm{ml}^{-1}$ ) digestion was performed at $37^{\circ} \mathrm{C}$ for $5 \mathrm{~min}$. The slides were immersed in $100 \mathrm{mmol}$ triethanolamine $1^{-1}(\mathrm{pH} \mathrm{8.0)}$ : $0.25 \%(\mathrm{v} / \mathrm{v})$ acetic anhydride $(5 \mathrm{~min} \times 2, \mathrm{RT})$, washed with $2 \times \mathrm{SSC}(\mathrm{RT})$ for $5 \mathrm{~min}$, followed by dehydration through an alcohol series to absolute ethanol.

Hybridization was performed in $50 \%(\mathrm{w} / \mathrm{v})$ formamide; $0.3 \mathrm{~mol} \mathrm{NaCl} \mathrm{l}^{-1} ; 10 \mathrm{mmol}$ Tris- $\mathrm{HCl} \mathrm{l}^{-1}$, pH 6.8; $10 \mathrm{mmol}$

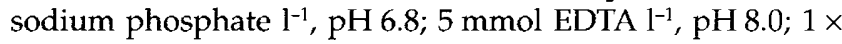
Denhardt's solution $(0.02 \%(\mathrm{w} / \mathrm{v})$ each of BSA, Ficoll and polyvinyl pyrrolidone); $10 \%(\mathrm{w} / \mathrm{v})$ dextran sulphate, $50 \mathrm{mmol} \mathrm{DTT} \mathrm{l}^{-1}, 1 \mathrm{mg}^{\mathrm{m}} \mathrm{\text {RNAm}} \mathrm{m}^{-1}$ and approximately $2 \times 10^{5}$ c.p.m. $\mu \mathrm{l}^{-1}{ }^{33} \mathrm{P}$-labelled sense or antisense riboprobe at $55^{\circ} \mathrm{C}$ for $18 \mathrm{~h}$. The slides were washed sequentially in $5 \times \mathrm{SSC}$, $50^{\circ} \mathrm{C}, 15 \mathrm{~min}$ twice; $2 \times \mathrm{SSC}$ : $50 \%$ formamide, $65^{\circ} \mathrm{C}, 30 \mathrm{~min}$; and four washes (each of $5 \mathrm{~min}$ ) of $2 \times \mathrm{SSC}, 37^{\circ} \mathrm{C}$. Tissue sections were then incubated at $37^{\circ} \mathrm{C}$ for $30 \mathrm{~min}$ with RNase A $\left(20 \mu \mathrm{g} \mathrm{ml}^{-1}\right.$; Boehringer Mannheim) in $400 \mathrm{mmol} \mathrm{NaCl} \mathrm{l}^{-1}$; $10 \mathrm{mmol}^{\text {Tris- }} \mathrm{HCl} \mathrm{l}^{-1}, \mathrm{pH} \mathrm{7.5;5} \mathrm{mmol} \mathrm{EDTA} \mathrm{l}^{-1}$. The RNase A was removed by washing the slides in $2 \times \mathrm{SSC}: 50 \%$ formamide at $65^{\circ} \mathrm{C}$ for $30 \mathrm{~min}$ followed by two $15 \mathrm{~min}$ washes in $2 \times \mathrm{SSC}$ and $0.2 \times \mathrm{SSC}$, both at $37^{\circ} \mathrm{C}$. Sections were dehydrated, air dried and coated with autoradiographic emulsion (LM-1 emulsion; Amersham International Plc, Amersham, Bucks). The emulsion-coated slides were exposed at $4^{\circ} \mathrm{C}$ for $2-3$ weeks. Slides were then developed (D19 developer, Kodak, Rochester, NY) and fixed. The sections were stained with haematoxylin and viewed and photographed using both light and dark field illumination on an Olympus BH-2 microscope. Hybridization of adjacent serial sections with the sense [ ${ }^{33}$ P]UTP-labelled OSCF and c-kit probes (negative controls) resulted in non-specific signal comparable with the background.

\section{Immunohistochemistry}

Paraffin wax-embedded sections were deparaffinized with xylene, rehydrated through a graded alcohol series and endogenous peroxidase activity was quenched by exposure to $3 \%(\mathrm{v} / \mathrm{v})$ hydrogen peroxidase in methanol for $30 \mathrm{~min}$. After antigen retrieval by heating the sections in a pressure cooker containing $0.01 \mathrm{~mol}$ citrate buffer $\mathrm{l}^{-1}$, pH 6.0 for $1 \mathrm{~min}$ (boiling at a pressure of $103 \mathrm{kPa}, 121^{\circ} \mathrm{C}$ ) the sections were washed in Tris- $\mathrm{HCl}$ buffer (TBS; $0.5 \mathrm{~mol}$ Tris (hydroxymethyl) methylamine $\left.\mathrm{I}^{-1}, 0.9 \%(\mathrm{w} / \mathrm{v}) \mathrm{NaCl}, \mathrm{pH} 7.6\right)$ three times for $10 \mathrm{~min}$. Sections were then incubated with nonimmune swine serum, diluted 1:5 in TBS for $30 \mathrm{~min}$ to reduce non-specific immunostaining. The appropriate primary antibodies were (i) for detection of c-kit: rabbit polyclonal $\mathrm{C}-19$ raised against a peptide corresponding to amino acids $958-976$ of human c-kit (Santa Cruz Biotechnology Inc, Santa Cruz, CA), diluted 1:30 (stock
$100 \mu \mathrm{g} \mathrm{ml}^{-\mathrm{i}}$ ), and (ii) for detection of ovine SCF: rabbit polyclonal antiserum (RGAS-005) raised against recombinant ovine SCF (RGAS-004), diluted 1:200, both anti-sera diluted in TBS $+0.1 \%(\mathrm{w} / \mathrm{v})$ BSA. Antisera were applied to the sections and incubated overnight at $4^{\circ} \mathrm{C}$ in a humid chamber. All other incubations and washes were performed at room temperature. The sections were then washed three times for $10 \mathrm{~min}$ in TBS and incubated for $30 \mathrm{~min}$ with the secondary antibody (biotinylated swine anti-rabbit IgG (DAKOPATTS, DAKO Corporation, Carpintria, CA) diluted 1:500 in TBS containing $0.1 \%(\mathrm{w} / \mathrm{v})$ BSA and $1 \%(\mathrm{v} / \mathrm{v})$ non-immune sheep serum. After the secondary antibody incubation, the sections were washed three times for $10 \mathrm{~min}$ in TBS and incubated with an avidin-biotinylated horseradish peroxidase complex (DAKOPATTS; made following the manufacturer's (DAKO Corporation) instructions) for $30 \mathrm{~min}$. The sections were given a further three 10 min washes in TBS and the immunoperoxidase activity visualized using the substrate 3,3'diaminobenzidene tetrahydrochloride $\left(0.5 \mathrm{mg} \mathrm{ml}^{-1}\right)$ in TBS + $0.03 \%(\mathrm{v} / \mathrm{v})$ hydrogen peroxidase in which the sections were incubated for $5 \mathrm{~min}$. After a final $5 \mathrm{~min}$ wash in TBS, the sections were counterstained in Gill's haematoxylin, dehydrated through graded alcohol and xylene and mounted under coverslips using DePeX (BDH Laboratory Supplies, Poole) mounting medium. Preincubating the clone C-19 antibody with its cognate peptide antigen and the rabbit anti-oSCF polyclonal antiserum (RGAS-005) with recombinant ovine SCF antigen (RGAS-004) overnight at $4^{\circ} \mathrm{C}$ abolished immunostaining. The absence of non-specific staining was also confirmed by the replacement of primary antibodies with non-immune rabbit serum.

\section{Production of rabbit anti-recombinant ovine stem cell factor polyclonal antibodies}

First strand cDNA was synthesized from ovine corpus luteum total RNA $(5 \mu \mathrm{g})$ using Superscript reverse transcriptase (Gibco BRL, Bethesda, MA). Nucleotide sequences encoding the extracellular domain of ovine stem cell factor (oSCF) (amino acids +1 to +206 ) were amplified by Taq DNA polymerase (Boehringer Mannheim) catalysed PCR; forward primer: 5'-GTGAATTCGCAAGGGATCTGCCGGAACCGTGTGA-3', reverse primer: 5'- GCAAGCTIAGCAAACCCGATCACAAGAGA-3' (Tisdall et al., 1997; GenBank accession number U89874). The forward and reverse primers included EcoRI and HindIII sites (underlined), respectively, required for subcloning into $\mathrm{pET}$ expression vectors (Novagen, Madison, WI). PCR conditions: $94^{\circ} \mathrm{C}$, $3 \mathrm{~min} ; 60^{\circ} \mathrm{C}, 3 \mathrm{~min} ; 72^{\circ} \mathrm{C}, 5 \mathrm{~min}$ (one cycle); $94^{\circ}, 30 \mathrm{~s} ; 62^{\circ} \mathrm{C}$, $1 \mathrm{~min} ; 72^{\circ} \mathrm{C}, 2 \mathrm{~min}$ ( 35 cycles); $72^{\circ} \mathrm{C}, 5 \mathrm{~min}$ (one cycle). Amplification products of the expected size $(0.6 \mathrm{~kb})$ were double-digested with EcoRI and HindIII, subjected to electrophoresis through a $1 \%(\mathrm{w} / \mathrm{v})$ low melting point agarose gel (FMC BioProducts, $\mathrm{ME}$ ) and in-gel ligated into pGem7Z (Promega). The identity of the cloned insert was confirmed by DNA sequencing. The EcoRI-HindIII fragment encoding the oSCF was subcloned into the expression vector pET23b(+) (Novagen), forming plasmid pET23boSCF, and transformed into the host strain BL21(DE3)pLysS (Novagen). 
The resulting fusion genes include vector sequences that encode an N-terminal T7.tag epitope and a C-terminal six histidine His-tag (Novagen). Recombinant protein production was induced and the identity of the recombinant protein further confirmed by its labelling with anti-T7.tag monoclonal (Novagen) and anti-recombinant human SCF polyclonal (R\&D Systems, Minneapolis, MN) on western blots. Induced cells were lysed by lysozyme treatment and sonication following the manufacturer's instructions (Novagen). The recombinant OSCF (RGAS-004) was solubilized in 6 mol urea $\mathrm{I}^{-1}$ and purified by $\mathrm{Ni}^{2+}$ affinity chromatography using NTAResin (Qiagen, Hilden). The purified recombinant OSCF (approximately $100 \mu \mathrm{g}$ ) was homogenized in STM (SpanTween-Marcol) adjuvant (Bokhout et al., 1981) and injected s.c. into New Zealand white rabbits. Secondary injections were given 4 and 8 weeks after the first injections and the rabbits exsanguinated 10 weeks after the first injection. Blood serum was collected and stored at $-20^{\circ} \mathrm{C}$. The presence of anti-roSCF antibodies (RGAS-005) was confirmed by using the rabbit antiserum as the primary antibody in Western blots carrying the roSCF antigen.

\section{Results}

\section{Stem cell factor gene expression in fetal gonads}

The localization of SCF mRNA in fetal ovaries at days 24-90 of gestation is shown in a series of photomicrographs (Fig. 1: days 24, 28, 30 and 40 of gestation; and Fig. 2: days 55, 75 and 90 of gestation). SCF mRNA was detected in the somatic cells of developing gonads from day 24 to day 90 of gestation with the highest expression becoming restricted over time to the ovarian cortex. At day 24 of gestation, SCF mRNA was detected in the genital ridge, cells of the giant glomerulus, mesonephric tubular epithelia and throughout the dorsal mesentery (Fig. 1a,b). At day 26 of gestation, SCF mRNA was localized uniformly throughout the gonad and also, to a lesser extent, in cells connecting the gonad and in the mesonephros itself (data not shown). At day 28 of gestation, SCF mRNA was detected throughout the somatic cell population of the gonad (ovary), although the cells located in the cortex contained higher mRNA concentrations than those within the medulla (Fig. 1c,d). At this time, only small (background) amounts of hybridization were observed in cells of the mesonephros and in the region connecting the gonad and mesonephros (Fig. 1d). Indeed, there was an abrupt reduction in SCF mRNA concentrations between the gonad and the region that connects the gonad to the adjacent mesonephros, indicated by a clear boundary in the silver grain density (Fig. 1d).

At both day 28 and day 30 of gestation, migrating mesonephros-derived cells formed a stream of cells continuous with the gonadal medulla with these cells expressing little or no SCF. A clear boundary was observed between SCF expressing cells within the gonad and non-SCF-expressing cells adjacent to the gonad (Fig. $1 \mathrm{~d}, \mathrm{f}$ ). From day 35 to day 40 of gestation (that is, after sexual differentiation), marked SCF expression was observed in the cortical region of the ovary (Fig. 1g,h). This pronounced cortical expression of the SCF gene continued to day 90 of gestation (Fig. 2a-f). At day 55 of gestation (Fig. 2a,b) the greatest SCF gene expression was observed in the ovarian surface epithelium and cortical somatic cells in the region where oogonia were undergoing mitosis. From day 55 of gestation, SCF-expressing cells within the ovarian cortex were morphologically distinguishable from non-expressing ovarian rete and fibroblast cells and were epitheloid in appearance (Fig. 3a). At day 75 of gestation, a similar pattern of SCF mRNA localization was observed (Fig. $2 c, d$ ). The decreasing gradient of SCF gene expression from the cortex to medulla (Figs 1 and 2) correlates with changes in germ cell maturation seen at higher magnification (Fig. 3). Germ cells undergoing mitosis and early meiosis were present in the outer ovarian cortex, while cells at more advanced stages of meiosis, atresia and early follicular formation were present within the innermost regions of the cortex. No SCF gene expression was observed in the granulosa cells of partially or fully enclosed primordial follicles in ovaries at day 75 of gestation (Fig. 3c). However, by day 90 of gestation, SCF gene expression was detected in groups of cells around primordial follicles, in granulosa cells (Fig. 2e,f) and in rete cells (data not shown).

\section{Stem cell factor protein in fetal gonads}

The distribution of the SCF protein in the mesonephros and ovary was examined in ovine fetuses at days $24,28,40$, 55 and 75 of gestation using a rabbit polyclonal antiserum raised against recombinant ovine SCF (Fig. 4). At day 24 of gestation, intense SCF immunostaining of the mesonephric epithelial cells was detected, while less immunostaining was apparent in the mesenchymal and epithelial cells of the developing gonadal ridge (Fig. 4a). The immunostaining of the gonadal ridge at day 24 of gestation at higher magnification (Fig. 4b) shows SCF in the epithelial cells and distributed among the underlying mesenchyme cells. Primordial germ cells migrating towards the gonadal ridge also stained positively with the anti-oSCF antiserum (Fig. 4b). At day 28 of gestation, SCF immunostaining was present throughout the developing ovary (Fig. 4c). There was also faint staining of the mesonephric glomeruli and strong staining of the mesonephric tubule epithelial cells. SCF immunostaining within the ovary resolved into a more clearly defined pattern by day 40 of gestation, with a band of intense staining within the ovarian cortex (Fig. 4d). Between the intensely staining band and the outer regions of the ovarian cortex there were also 'nests' of immunostained cells, together with diffuse regions of SCF protein staining within the ovarian medulla. In the adjacent mesonephros, SCF was strongly localized to the epithelial cells of the mesonephric tubules (Fig. 4d). At day 55 of gestation, SCF was localized within the cortex to the surface epithelium (data not shown) and to cell clusters (chords) containing both somatic cells and germ cells (Fig. 4e).

At day 75 of gestation, a gradient of immunostaining was noted with intense labelling in the cortex and the least intense labelling in the medulla (Fig. 4f). SCF staining was apparent in the nests of germ cells located at the periphery of the ovary (Fig. 4g) and in both the oocytes and granulosa 

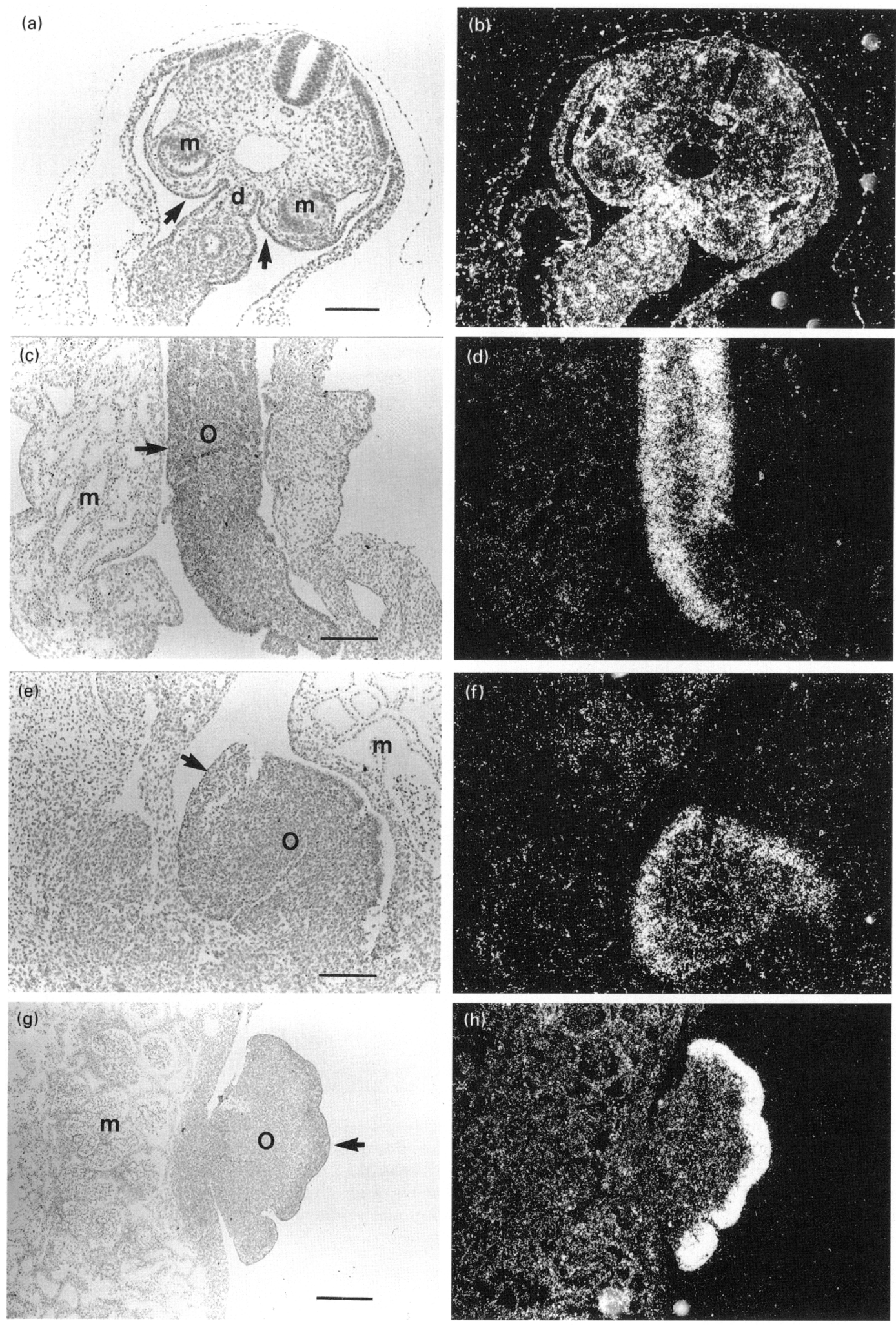

Fig. 1. Distribution of mRNA encoding stem cell factor (SCF) in sheep fetal ovaries. A 33 -labelled antisense riboprobe of the oSCF gene was hybridized to tissue sections of sheep fetal ovaries at days $24,28,30$ and 40 of gestation. Left, lightfield photomicrographs; right, corresponding darkfield photomicrographs. (a,b) Day 24 fetus, showing SCF expression in the genital ridge (arrows), dorsal mesentery (d) and mesonephros ( $\mathrm{m}$ ); (c,d) day 28 fetal ovary (o); (e,f) day 30 fetal ovary; $(\mathrm{g}, \mathrm{h})$ day 40 fetal ovary showing SCF mRNA localized predominantly in the ovarian cortex (arrow) but low expression in mesonephros. Scale bars represent $160 \mu \mathrm{m}(\mathrm{a}-\mathrm{f})$ and $400 \mu \mathrm{m}(\mathrm{g}, \mathrm{h})$. 

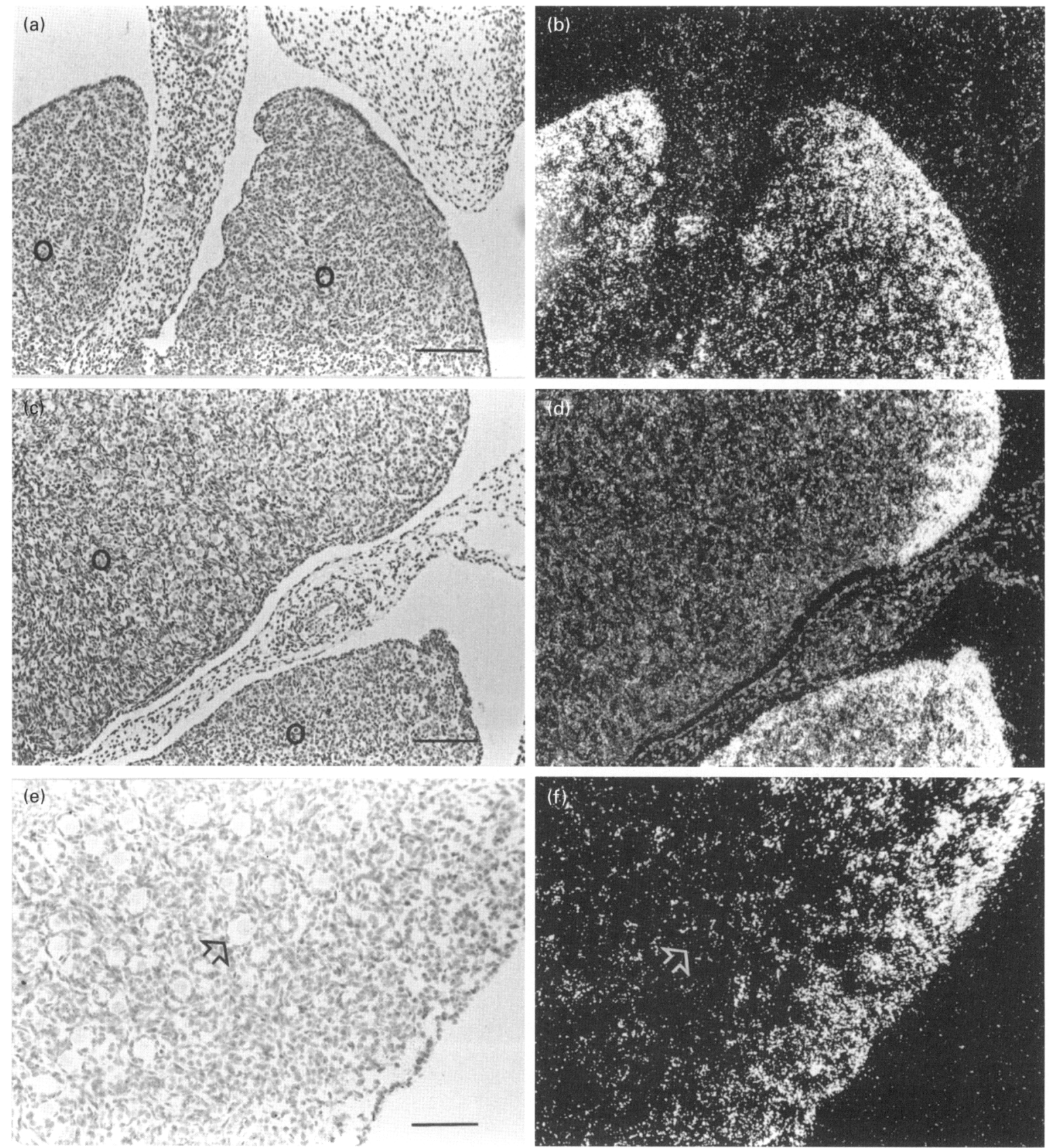

Fig. 2. Distribution of mRNA encoding stem cell factor (SCF) in sheep fetal ovaries. A "P-labelled antisense riboprobe of the OSCF gene was hybridized to tissue sections of sheep fetal ovaries at days 55, 75 and 90 of gestation. Left, lightfield photomicrographs; right, corresponding darkfield photomicrographs. (a,b) Day 55 fetal ovary (o) showing SCF localized predominantly in ovarian cortex with some expression around and occasionally in nests of germ cells in the ovarian medulla; (c,d) day 75 fetal ovary showing SCF expression in ovarian cortex groups of mitotic germ cells; (e,f) day 90 fetal ovary showing SCF expression in ovarian cortex and around primordial follicles (open arrow). Scale bars represent $160 \mu \mathrm{m}$ (a-d) and $80 \mu \mathrm{m}$ $(\mathrm{e}, \mathrm{f})$.

cells forming the primordial follicles within the ovary (Fig $4 h)$. The pattern of immunostaining at day 90 of gestation resembled that at day 75 of gestation, with SCF immunostaining of the peripheral germ cell nests still present, as well as immunostaining of both oocytes and granulosa cells of the primordial follicles (data not shown).

\section{C-kit gene expression in fetal gonads}

The localization of c-kit mRNA in fetal ovaries at different development stages is shown (Figs 5,6 and 7). C-kit gene expression was evident at day 24 of gestation in both germ cells (Fig. 7a,b) and somatic cells in the genital ridge (Fig. 5a,b), 


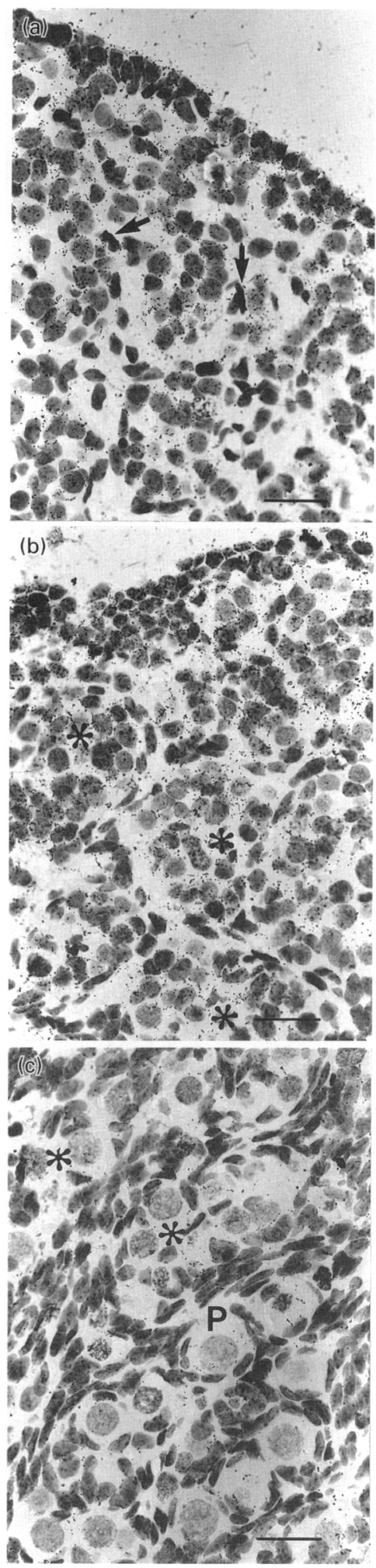

Fig. 3. Lightfield photomicrographs of fetal sheep ovaries hybridized to a ${ }^{33} \mathrm{P}$-labelled stem cell factor (SCF) antisense riboprobe. (a) Day 55 fetal ovary showing SCF expression in epithelial cells and in rounded cortical cells and its absence in fibroblast-like cells (arrows). (b) Day 75 fetal ovary showing SCF expression in the outer region of the cortex in somatic cells in and around the ventral aorta and in the dorsal mesentery (Fig. 5a,b). In addition, there was evidence of c-kit expression in the mesonephros and the neural tube (Fig. 5a,b). By day 28 of gestation, discreet areas of hybridization over both germ cells and somatic cells were evident both in, and beneath, the developing gonad (Fig. 5c,d). By day 30 of gestation, a discontinuous ring of punctate hybridization was observed around the cortical region of the gonad (Fig. 5e,f). By day 40 of gestation, there was an intense band of c-kit expression in the ovarian cortex, associated with both germ cells and somatic cells, and punctate areas of expression were also observed in clusters of germ cells in the central region of the gonad (Fig. $5 \mathrm{~g}, \mathrm{~h}$ ). At day 55 of gestation, germ cells were grouped together in cords, the majority of which were in a pre-meiotic state: $c$-kit mRNA was localized in the germ cells comprising these cords (Figs 6a,b and 7c). In contrast, at day 75 of gestation, the majority of germ cells within the cords were undergoing meiosis and c-kit expression intensity was much lower (near background) within such cells (Figs 6c,d and $7 \mathrm{~d}$ ). However, expression was evident in germ cells in cords that were either pre-meiotic (that is, closer to the ovarian cortex), or had reached the diplotene stage of meiosis (that is, closest to the ovarian medulla). C-kit expression was also seen in germ cells in the cortex not enclosed in cords and in oocytes further into the medulla that were partially or fully enclosed by granulosa cells (Fig. 6d). By day 90 of gestation, cords enclosing germ cells were no longer present as most germ cells had become isolated oogonia or oocytes. C-kit expression was detected in the oocytes of developing follicles but not in the isolated oogonia (Fig. 6f).

\section{Localization of $c$-kit protein in the fetal ovine gonad or ovary using immunohistochemistry}

The localization of c-kit protein in fetal ovaries at different developmental stages is shown (Fig. 8). At day 24 of gestation, c-kit immunostaining was observed in mesonephric epithelial cells while small amounts of staining were also detected in the mesenchymal and epithelial cells of the developing gonadal ridge (Fig. 8a,b). In addition to the immunostaining in the region of the developing gonad, very intense immunostaining was noted in neurones extending from the ventral portion of the neural tube (Fig. 8a). At day 28 of gestation, c-kit immunostaining was present in germ cells and somatic cells within the ovary and also the mesonephric epithelium (Fig. 8c).

At day 40 of gestation, c-kit immunostaining was present throughout the ovary (Fig. 8d) with intense labelling of cell clusters that included germ cells. A clear boundary was noted between the ovary (positive c-kit immunostaining) and the mesonenephric cells adjacent to the ovary (no staining) (Fig. 8d). However, the mesonephric tubule

around germ cell cords (asterisks). (c) Day 75 fetal ovary showing inner region of the cortex of the same ovarian section, demonstrating low and absent SCF expression in and around germ cell cords (asterisks) and absence of expression in the granulosa cells of primordial follicles $(P)$. Scale bar represents $27 \mu \mathrm{m}$. 

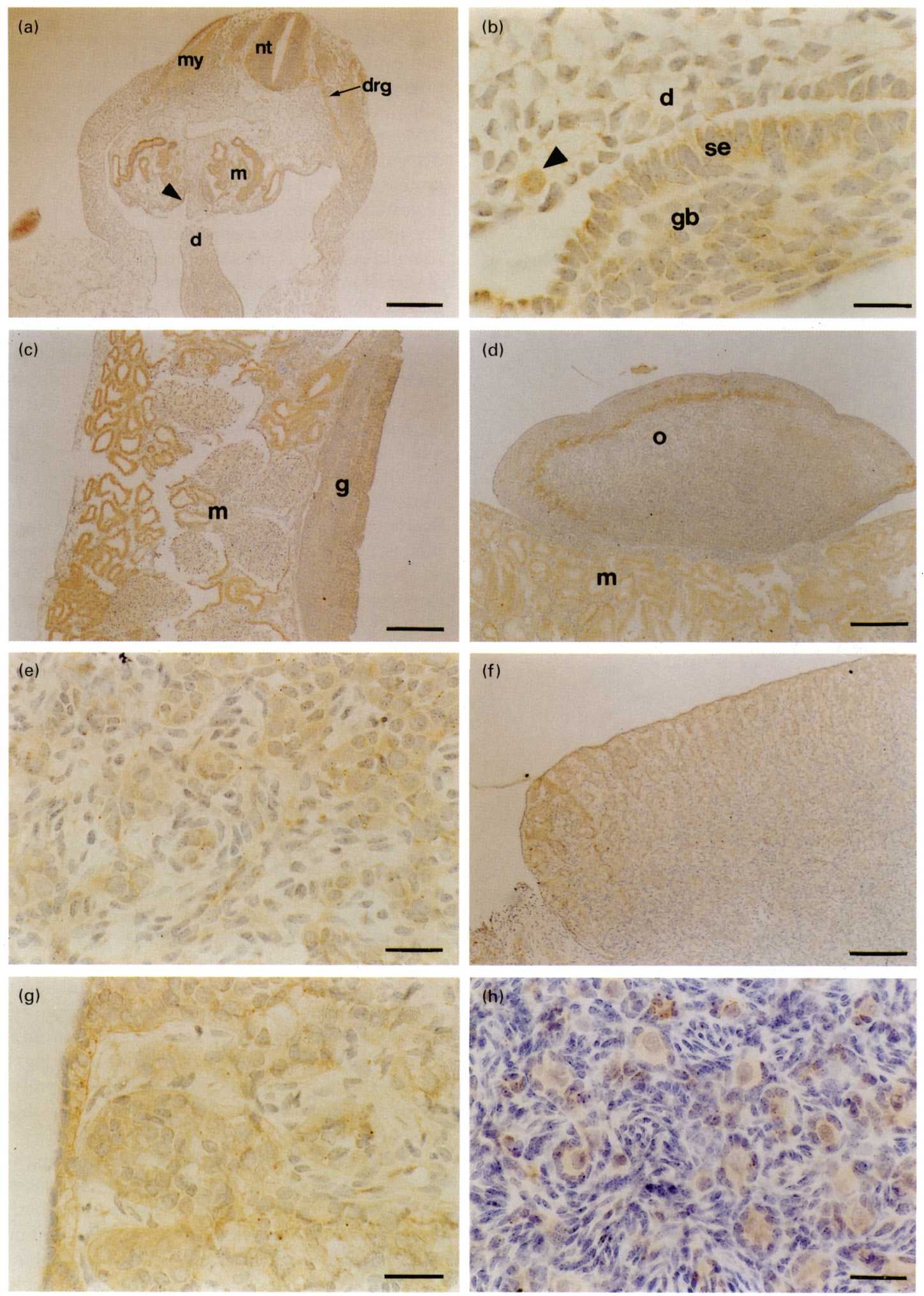

Fig. 4. For legend see facing page.

epithelial cells were intensely labelled with the anti-c-kit antisera (Fig. 8d). At day 55 of gestation, staining of the surface epithelium (Fig. 8f) and also intense labelling of cell clusters in the cortex was evident (Fig. 8e,f): some of these labelled cells included oogonia and oocytes. At day 75 of gestation, labelling of the surface epithelium was evident, as were the oogonia and newly forming oocytes in the cortex (Fig. 8g).

The findings of c-kit immunostaining at day 90 of gestation (Fig. 8h) were similar to those found at day 75 of gestation (Fig. 8g). 
Relationships between stem cell factor and c-kit mRNA and protein localization in the gonad

The associations between SCF and c-kit mRNA and protein within the various regions or cell types of the developing ovary from day 24 to day 90 of gestation are summarized (Table 1). In general, SCF and c-kit mRNA and protein were localized to the same ovarian compartments and cell types. The major exceptions were that SCF mRNA was not localized to germ cells or oocytes, whereas SCF protein was commonly localized to these cells. In addition, SCF mRNA was not localized to granulosa cells in newly forming follicles at day 75 of gestation, whereas SCF protein was found at that time. Likewise, c-kit mRNA was not localized to oocytes of newly forming follicles at day 75 of gestation, whereas c-kit protein was present. Furthermore, c-kit mRNA and protein were not localized in granulosa cells of primordial or primary follicles at days 75 or 90 of gestation.

\section{Discussion}

At day 24 of gestation, cells within the gonad, the giant glomerulus of the mesonephros, epithelial cells of the mesonephric tubules and cells in the dorsal mesentery were all expressing the SCF gene and SCF protein. These results are consistent with the in situ hybridization studies in which SCF mRNA has been localized to mesodermal cells along the migratory path of primary germ cells (PGCs) from the dorsal aorta to the genital ridge in mice at embryonic day 10 (Matsui et al., 1990; Keshet et al., 1991). In the present study, at day 24 of gestation, c-kit gene expression and protein were both localized to the germ cells and somatic cells of the gonad and also to the mesonephros, dorsal mesentery, dorsal aorta (data for the protein not shown) and neural tube. These findings are consistent with studies in mice that localized c-kit mRNA to PGCs at the base of the allantois at day 7.5 after mating, along the mesentery in the vicinity of the dorsal aorta at embryonic day 10 , and in the PGCs in the genital ridges of mid-gestation embryos (day 12.5 after mating) (Orr-Urtreger et al., 1990; Keshet et al., 1991; Manova and Bachvarova, 1991). In sheep fetuses at day 24 of gestation, $\mathrm{c}$-kit protein but not c-kit mRNA was localized to the dorsal root ganglia and, to a lesser extent, in the myotomes. This finding indicates either the persistence of membrane-bound c-kit protein or the presence of a soluble form of c-kit (Tanikawa et al., 1998). The persistence of membrane-bound c-kit protein seems the most likely explanation, since the antibody recognizes a peptide sequence corresponding to amino acids $958-976$ of human c-kit, which is in the cytoplasmic region of the cell, neutralization of the c-kit antibody with the aforementioned peptide sequence inhibited binding, and the antibody binding was localized principally to specific cell types rather than to extracellular regions. The ovine peptide sequence at the carboxy-terminal of c-kit remains unknown, but the predicted homologies from the GenBank database for rat, chicken, mouse, bovine and goat c-kit were $78-84 \%$.

In the present studies, the somatic cells migrating into the gonad at days 24-26 of gestation were expressing the SCF gene whereas, at day 28 of gestation, there was no evidence of gene expression in the continuum of cells from the mesonephros into the gonad. This finding is consistent with results in which SCF gene expression along the PGC migratory route ceased by embryonic day 11.5 when PGC colonization of the gonad was complete, while expression continued in the gonad in mice (Keshet et al., 1991). In sheep fetuses, the first evidence of differential expression was seen by day 28 of gestation and SCF mRNA was more pronounced in a broad area delineating the cortical region of the gonad with much lower gene expression occurring in the medullary region. This pattern of SCF gene expression became increasingly more concentrated within the cortex up to day 40 of gestation, which further distinguished this region from the medulla. Moreover, during this period, SCF protein appeared as a dense band in the cortical region with clusters of cells also being labelled immediately beneath the surface epithelium. Collectively, these results indicate that cells containing SCF mRNA in the ovary before day 28 of gestation derive from the gonadal blastema and migrating mesangial and epithelial cells from the underlying mesonephros, and that the descendants of these cells continue to express SCF within the ovary. By contrast, mesonephric cells migrating from day 28 of gestation onwards and which contribute to the ovarian medulla do not contain SCF mRNA, even though many of these cells contain SCF protein. Zamboni et al. (1979) describe the gonadal blastema, and the mesangial and epithelial cells of the mesonephros of 24-29 day old embryos as establishing close associations with primordial germ cells. The results of the present study are consistent with the view that cells expressing SCF support the early growth and survival of germ cells (Pesce et al., 1993; Packer et al., 1994). There was intense c-kit gene expression in the ovarian cortex and punctate expression in the medulla from day 30 to day 40 of gestation. The localization of c-kit protein to germ cells was similar to that of mRNA.

Fig. 4. Stem cell factor (SCF) localization by immunocytochemistry in female sheep mesonephros, undifferentiated gonad and ovary at different stages of fetal life. SCF localized in: (a) gonadal ridge (arrowhead), and mesonephros (m) at day 24 of gestation. Note that SCF was also localized in the neural tube (nt), dorsal root ganglia (drg), myotome (my) and dorsal mesentery (d); (b) surface epithelium (se) and gonadal blastema $(\mathrm{gb})$ and also primordial germ cell (arrowhead) and dorsal mesentery (d) at day 24 of gestation; (c) mesonephros (m) and gonad $(\mathrm{g})$ at day 28 of gestation; (d) mesonephros $(\mathrm{m})$ and ovary $(\mathrm{o})$ at day 40 of gestation (note the intense band of staining in the ovarian cortex and punctate staining between the band and surface epithelium); (e) both germ cells and somatic cells of the ovary immediately adjacent to the germ cells at day 55 of gestation; (f) ovary at day 75 of gestation (note the gradient of staining from the cortex to the medulla and the concentration of staining in the cord-like structures); (g) surface epithelium, somatic cells and germ cells in the ovarian cortex at day 75 of gestation; and (h) primordial follicles including both the oocytes and granulosa cells at day 90 of gestation. Scale bars represent $286 \mu \mathrm{m}$ (a), $16 \mu \mathrm{m}(\mathrm{b}), 160 \mu \mathrm{m}(\mathrm{c}, \mathrm{f}), 263 \mu \mathrm{m}(\mathrm{d})$ and $27 \mu \mathrm{m}(\mathrm{e}, \mathrm{g}, \mathrm{h})$. 
(a)
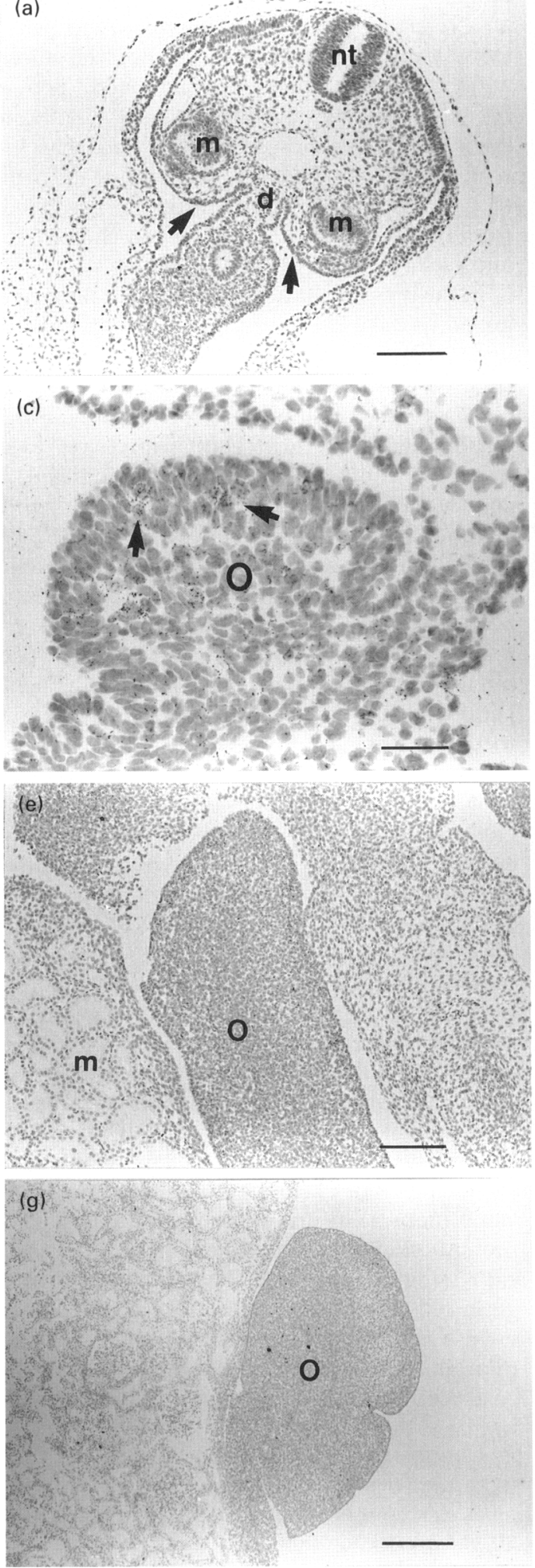
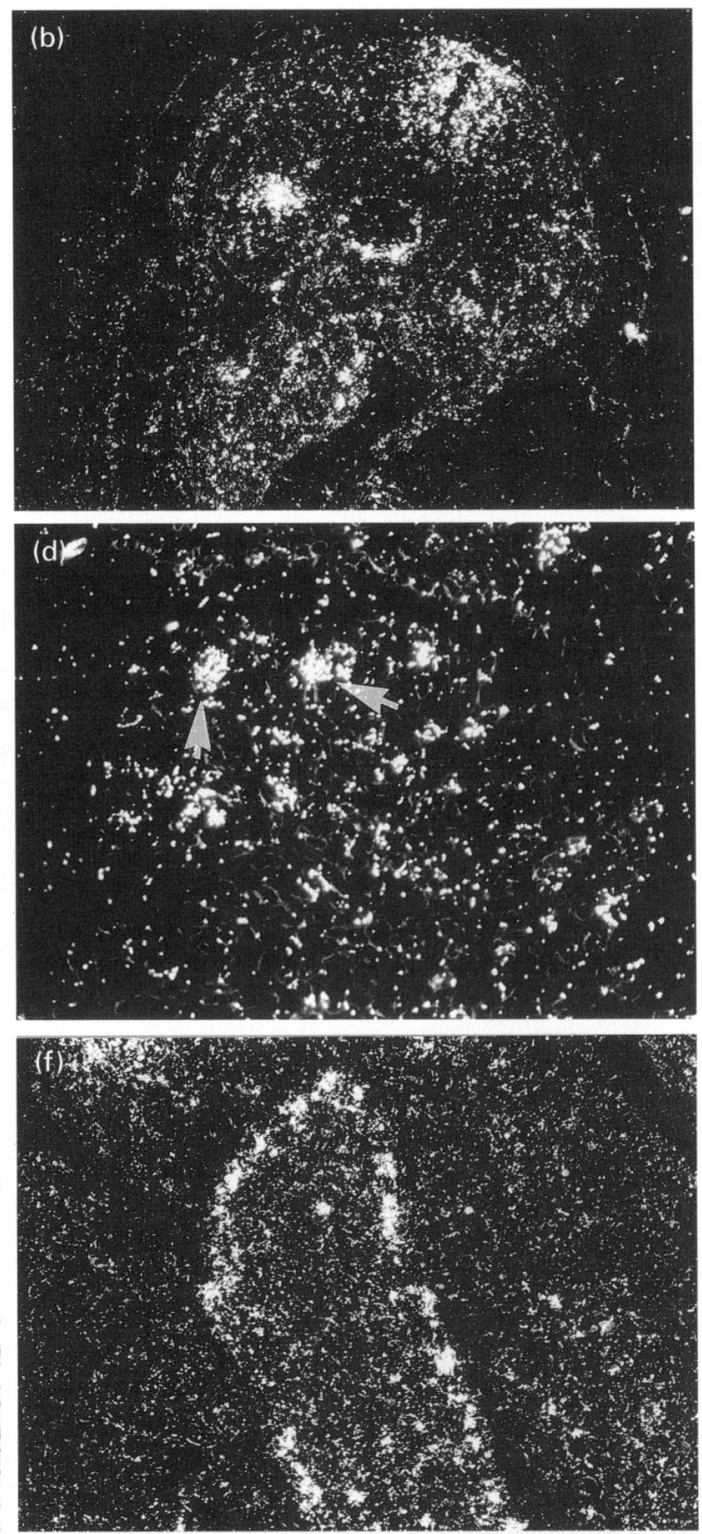

(h)

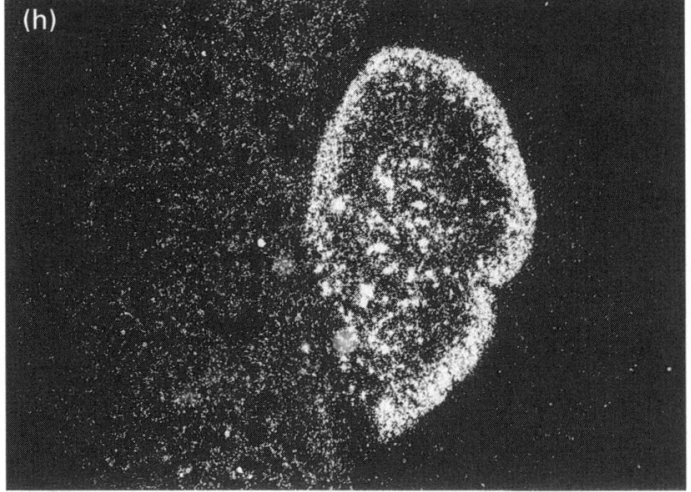

Fig. 5. Distribution of $m$ RNA encoding c-kit in sheep fetal ovaries. A ${ }^{33} \mathrm{P}$-labelled antisense riboprobe of the ovine c-kit gene was hybridized to tissue sections of sheep fetal ovaries at days $24,28,30$ and 40 of gestation. I.eft, lightfield photomicrographs; right, corresponding darkfield photomicrographs. (a,b) Day 24 fetus, showing c-kit mRNA localized in the genital ridge (arrows), dorsal mesentery $(\mathrm{d})$ mesonephri $(\mathrm{m})$ and neural tube $(\mathrm{nt})$; (c,d) day 28 fetal ovary $(\mathrm{O})$ showing c-kit localized to germ cells (arrows) and somatic cells; $(\mathrm{e}, \mathrm{f})$ day 30 fetal ovary with $\mathrm{c}$-kit mRNA more intensely labelled in ovarian $(\mathrm{o})$ cortex and background labelling in mesonephros $(\mathrm{m}) ;(\mathrm{g}, \mathrm{h}) \mathrm{day}$ 40 fetal ovary, showing c-kit mRNA intensely localized to germ cells in the ovarian (o) cortex and medulla. Scale bars represent 160$) \mu \mathrm{m}(\mathrm{a}, \mathrm{b}, \mathrm{e}, \mathrm{f}), 40 \mu \mathrm{m}(\mathrm{c}, \mathrm{d})$ and $400 \mu \mathrm{m}(\mathrm{g}, \mathrm{h})$. 

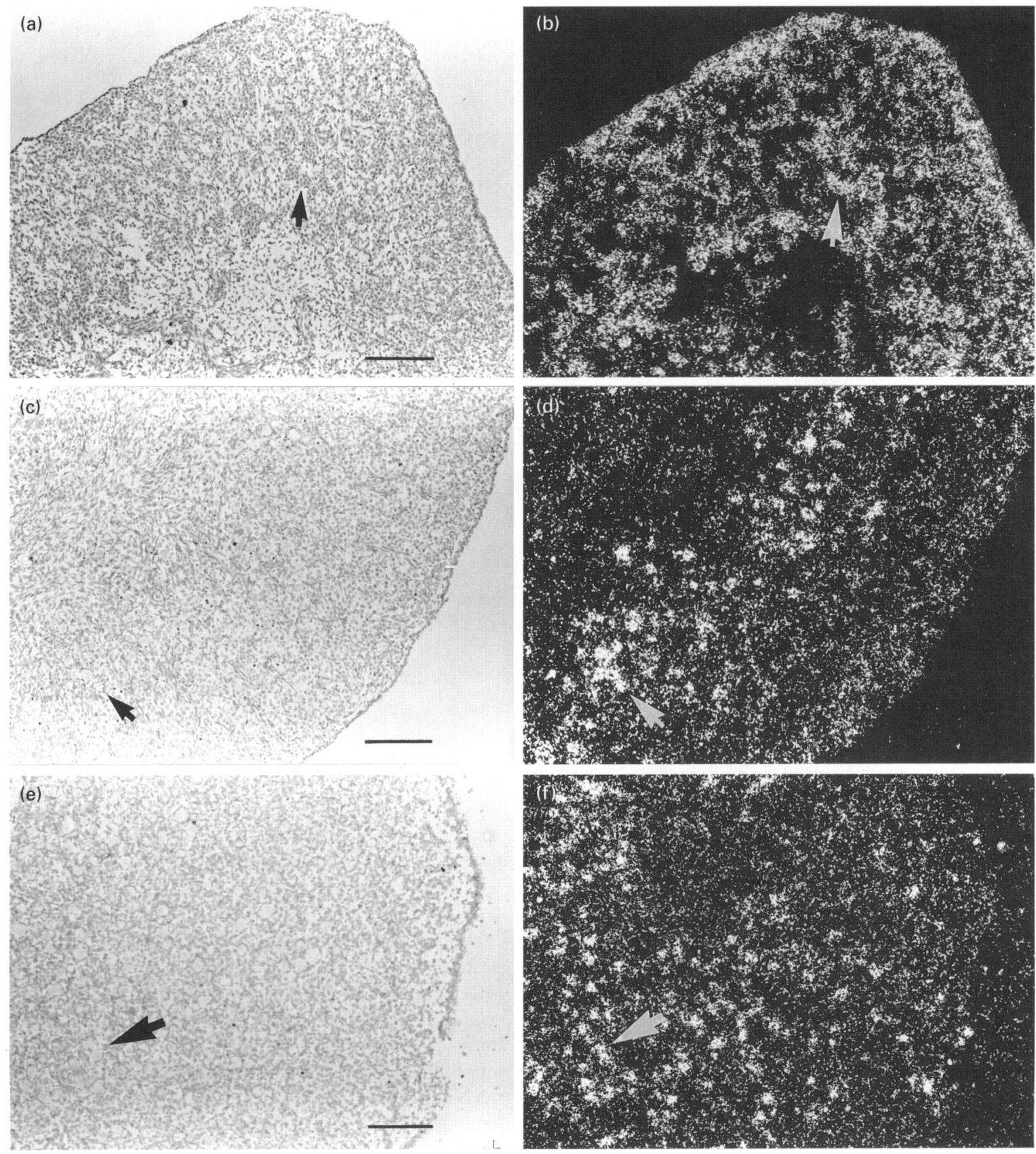

Fig. 6. Distribution of mRNA encoding c-kit in sheep fetal ovaries. A ${ }^{33}$-labelled antisense riboprobe of the ovine c-kit gene was hybridized to tissue sections of sheep fetal ovaries at days 55, 75 and 90 of gestation. Left, lightfield photomicrographs; right, corresponding darkfield photomicrographs. (a,b) Day 55 fetal ovary showing c-kit mRNA localized to cords of predominantly pre-meiotic germ cells (arrow); (c,d) day 75 fetal ovary showing c-kit mRNA localized to oocytes of primordial follicles (arrow); (e,f) day 90 fetal ovary showing c-kit mRNA localized in oocytes of primordial follicles (arrow) in the ovarian medulla and in a few pre-meiotic germ cells in the cortex. Scale bars represent $160 \mu \mathrm{m}(\mathrm{a}-\mathrm{d})$ and $80 \mu \mathrm{m}(\mathrm{e}, \mathrm{f})$.

A marked gradient of SCF mRNA and protein localization was noted in the ovary from day 55 to day 75 of gestation. The highest concentrations of both message and protein were noted in the outer regions of the cortex and these decreased towards the innermost regions of the cortex and medulla. In essence, both mRNA and protein were localized in somatic cells associated with oogonia and germ cells undergoing early meiosis. Lower expression occurred in somatic cells adjacent to germ cells at more advanced stages of meiosis or in cells undergoing atresia. Furthermore, the granulosa cells of the first forming follicles in the innermost regions of the cortex at day 75 of gestation did not contain SCF mRNA, although SCF protein was localized in both the germ cells and granulosa cells of these newly forming follicles. The absence of SCF mRNA in the granulosa cells of the first forming follicles in the innermost regions of the ovarian cortex at day 75 of gestation is consistent with the view that the 'organized' phase of migrating mesonephric 

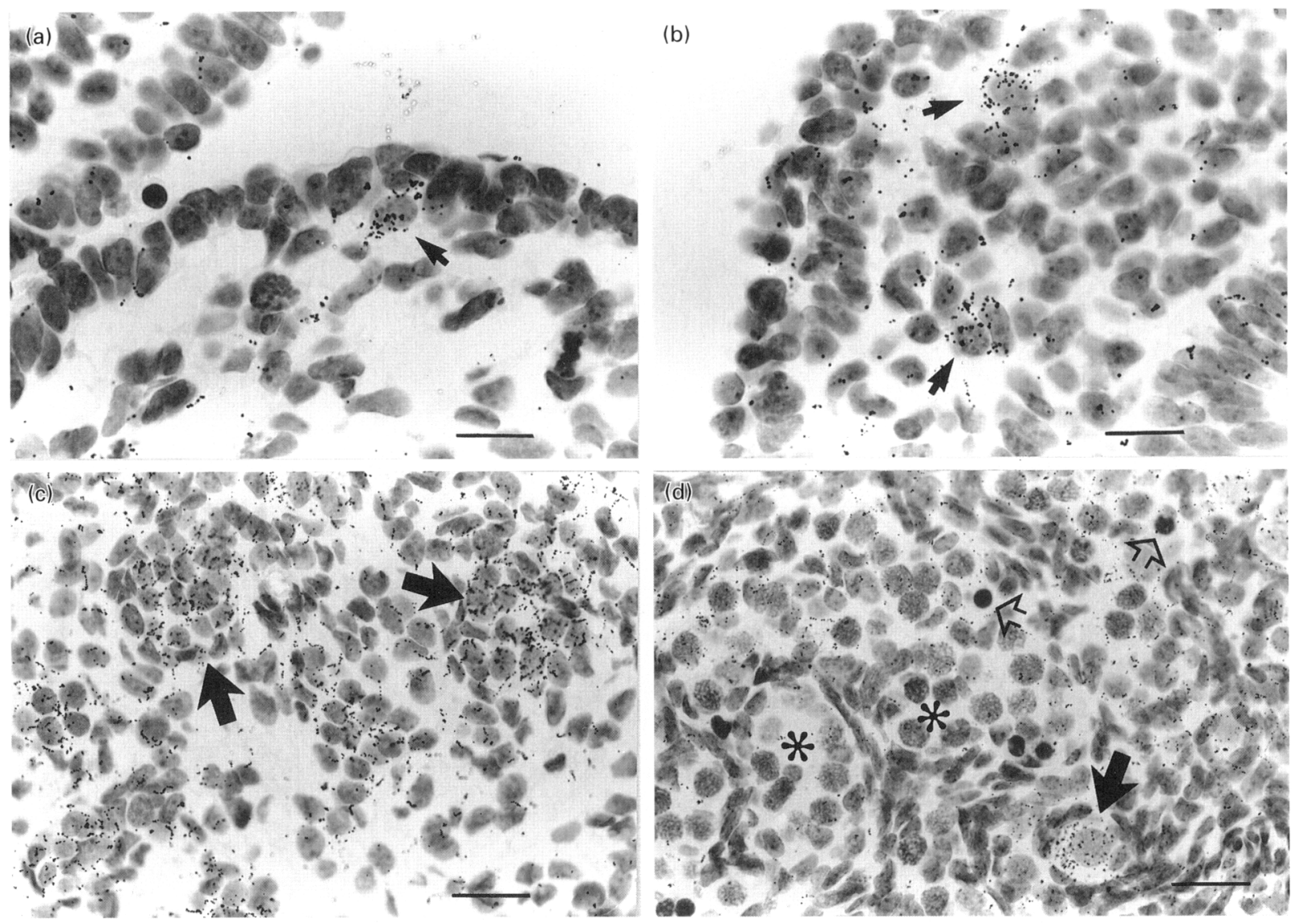

Fig. 7. Lightfield photomicrographs showing c-kit mRNA localized (a) in a germ cell (arrow) in the genital ridge and (b) in a germ cell (arrows) in the dorsal mesentery in a day 24 fetus; (c) in groups of pre-meiotic germ cells (arrows) in a day 55 ovary; and (d) in the oocyte of a primordial follicle (arrow) but absent in meiotic (asterisks) and atretic (open arrow) germ cells in a day 75 ovary. Scale bars represent $16 \mu \mathrm{m}(\mathrm{a}, \mathrm{b})$ and $27 \mu \mathrm{m}(\mathrm{c}, \mathrm{d})$.

cells contributes to the granulosa cells of these newly forming follicles (Byskov and Lintern-Moore, 1973; Zamboni et al., 1979). Moreover, the presence of SCF protein in these follicles, notwithstanding the absence of localized gene expression, is consistent with the view that the ligand is present in a soluble form and that it is expressed by somatic cells at another site. The antisera against SCF used in the present study recognizes both the membrane-bound and soluble forms. Thus, it is likely that, in the fetal sheep ovary, both membrane and soluble forms are present during early follicular formation and growth (Ismail et al., 1997). Whether all granulosa cells arise from mesonephric cells migrating after day 28 of gestation or whether they originate from cells from both the 'organized' and 'disorganized' phases cannot be established from the present study. Nevertheless, the cortical gradient of SCF gene expression (and protein localization) in the sheep ovary is different from the pattern observed in mice. In mice, SCF expression was observed in the medullary region of the ovary at birth (Manova et al., 1993). Unlike sheep, SCF gene expression in mice was highest in the region where the first wave of growing follicles was present (Manova et al., 1993). Moreover, in mice, the primordial follicles in the periphery derive mainly from cells not expressing SCF, indicating that follicle cells in this species arise from two separate extraovarian sources (Manova et al., 1993).
At day 55 of gestation, c-kit gene expression and c-kit protein were seen in germ cells both outside and within germ cell cords. At this stage of development, the majority of germ cells within the cords were pre-meiotic, with a few entering the very early stages of meiosis. By day 75 of gestation, the majority of germ cells within the cords did not express c-kit mRNA, although most immunostained for c-kit protein. It is likely that most of these germ cells were undergoing meiosis (Smith et al., 1993; Tisdall et al., 1997). The germ cells in the ovarian cortex that still expressed c-kit, both in and outside cords, appeared to be premeiotic, while germ cells in the cords closest to the ovarian medulla expressing c-kit appeared to have completed the first stages of meiosis. c-kit gene expression was also seen in oocytes deeper within the medulla that were partially or fully enclosed by granulosa cells. This cessation of c-kit gene expression in germ cells as they enter and pass through meiotic prophase is in agreement with studies in mice (Manova et al., 1990; Manova and Bachvarova, 1991) and are attributable to structural changes affecting chromatin during the meiotic process.

The presence of SCF-c-kit expression in areas of germ cell proliferation and the absence of SCF-c-kit expression in and around regions where large numbers of germ cells are undergoing atresia are consistent with results of in vitro studies showing that SCF supports germ cell growth (Packer et al., 1994) and inhibits apoptosis (Pesce et al, 1993; Carson et 

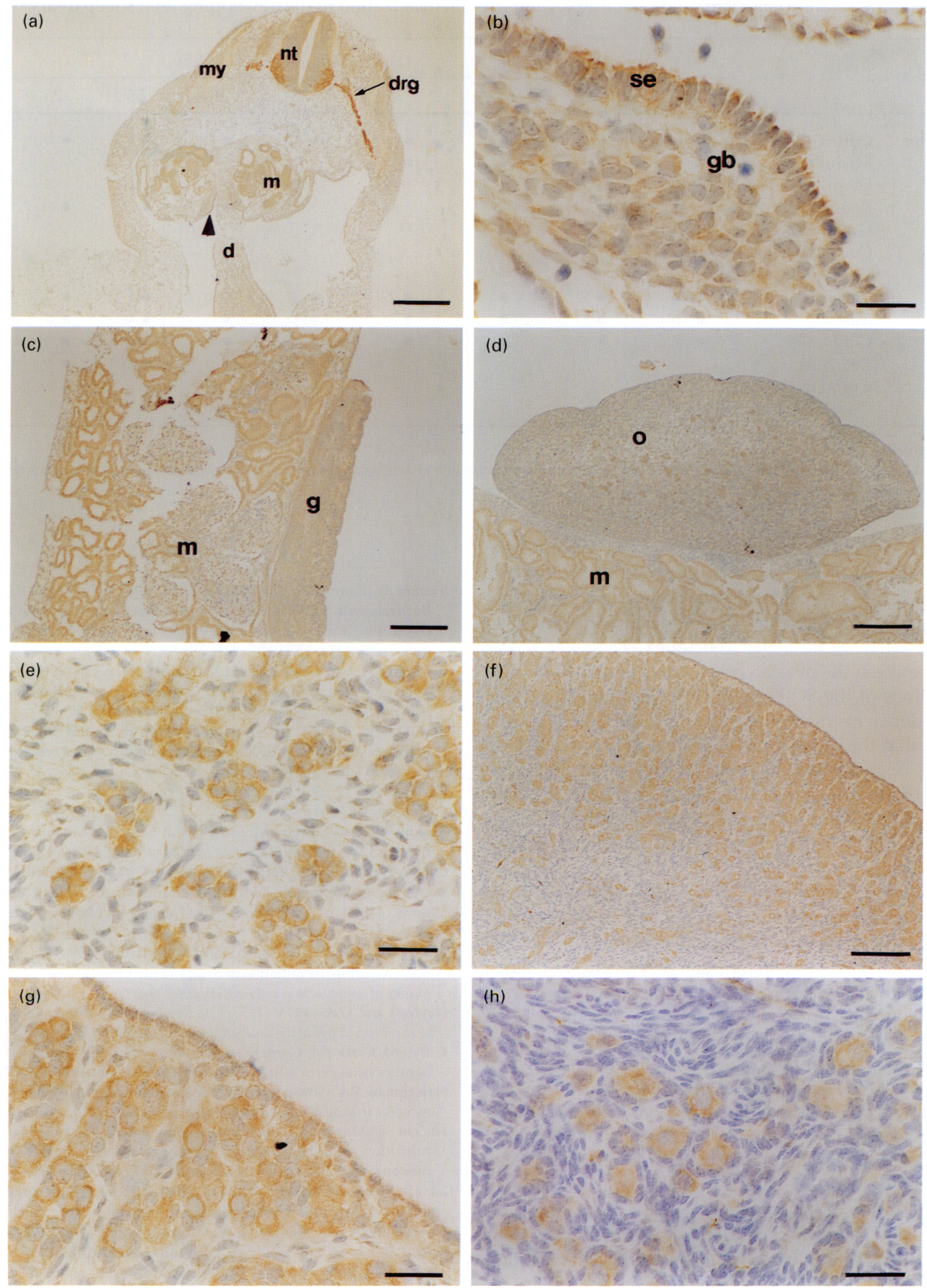

Fig. 8. C-kit localized by immunocytochemistry in female sheep mesonephros, undifferentiated gonad and ovary at different stages of fetal life. C-kit localized in: (a) gonadal ridge (arrowhead) and mesonephros (m) at day 24 of gestation (note that c-kit is also localized in the neural tube (nt), dorsal root ganglia (drg) and myotome (my)); $d$, dorsal mesentery; (b) ovarian surface epithelium (se) and gonadal blastema ( $\mathrm{gb}$ ) at day 24 of gestation; (c) mesonephros $(\mathrm{m})$ and gonad $(\mathrm{g})$ at day 28 of gestation; (d) mesonephros $(\mathrm{m})$ and ovary $(\mathrm{o})$ at day 40 of gestation (note the increasingly punctate staining intensity in the ovary at this age); (e) germ cells at day 55 of gestation; (f) surface epithelium and germ cells at day 75 of gestation (note that staining is mainly in the cortical regions of the ovary); $(\mathrm{g})$ surface epithelium and germ cells in the ovarian cortex at day 90 of gestation; (h) primordial follicles at day 90 of

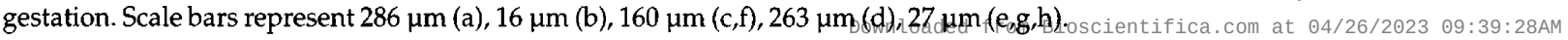


Table 1. Stem cell factor and c-kit mRNA and protein localization in the developing fetal sheep ovary

\begin{tabular}{|c|c|c|c|c|c|c|c|c|c|c|}
\hline $\begin{array}{l}\text { Gonadal region } \\
\text { or cell type }\end{array}$ & & \multicolumn{9}{|c|}{ Day of gestation } \\
\hline \multirow{3}{*}{ Stem cell factor } & Medulla & - 0 & - 0 & - 0 & - 0 & & & & & \\
\hline & Germ cells & 0 & 0 & 0 & 0 & 0 & o & o & o & 0 \\
\hline & Rete cells & & & & & & - o & - o & $\bullet$ & - 0 \\
\hline \multirow[t]{5}{*}{ C-kit } & Cortex $^{1}$ & - 0 & - 0 & - 0 & - 0 & - 0 & - 0 & - 0 & - 0 & - 0 \\
\hline & Medulla & - 0 & - 0 & - 0 & - 0 & - 0 & - 0 & - 0 & - 0 & - 0 \\
\hline & Germ cells & - 0 & - 0 & - 0 & - 0 & - 0 & - 0 & - 0 & - $\circ$ & - 0 \\
\hline & Rete cells & & & & & & $\bullet$ & $\bullet \circ$ & - 0 & \\
\hline & Granulosa cells & & & & & & & & & \\
\hline
\end{tabular}

$\bullet$, mRNA; 0 , protein.

${ }^{1}$ At days 24 and 26 of gestation, the cortex refers to the surface epithelium and medulla to the gonadal blastema. At day 28 and later ages, the cortex refers to both the surface epithelium and somatic cells of the cortical region.

al., 1994; Mikori et al., 1995; Liesveld et al., 1996). Overexpression of $\mathrm{Bcl}-2$ or $\mathrm{BclxL}$ in male germ cells of transgenic mice prevents the early and massive wave of apoptosis that normally occurs during the first round of spermatogenesis in the testis (Furichi et al., 1996; Rodriguez et al., 1997). The similarity between the ovarian phenotypes observed in mice with mutations at the SCF or c-kit loci (Besmer et al., 1993) and Bcl-2-deficient mice (Ratts et al., 1995) led to the suggestion that the downstream survival actions of SCF on developing oogonia and oocytes are linked to enhanced expression of the Bcl-2 gene (Tilly, 1996). Therefore, it would be interesting to examine the expression pattern of $\mathrm{Bcl}$ $2-B c l x L$ in relation to female germ cell development and atresia in sheep.

Between day 90 and day 135 of gestation SCF gene expression is progressively downregulated in the ovarian cortex and, at the same time, appears in the granulosa cells of developing follicles (Tisdall et al., 1997). These results, together with those of the present study, indicate that ovarian SCF-producing cells up to day 90 of gestation are derived predominantly from the blastema of undifferentiated cells of the early developing genital ridge and from the first wave of migrating cells of the mesonephros. As there is morphological evidence supporting the view that granulosa cells are derived from the rete ovarii of mesonephric origin (Byskov and Lintern-Moore, 1973; Zamboni et al., 1979), SCF gene expression in granulosa cells and in rete cells at and beyond day 90 of gestation (Tisdall et al. 1997) may result from SCF gene expression being independently switched on in cells arising from the second wave of mesonephric cell migration at this time.

The authors would like to thank N. Hudson, A. O'Connell and T. Lundy for animal care, surgery and tissue collection; L-A. Still and L. O'Donovan for preparation of histological material; A. Barkus for preparation of figures; $S$. Swaney for secretarial assistance and the NZ Foundation for Research, Science and Technology for financial support.

\section{References}

Besmer P, Manova K, Duttlonger R, Huang EJ, Packer A, Gyssler $C$ and Bachvarova RF (1993) The kit ligand (steel factor) and its receptor $c$-kit: pleotropic roles in gametogenesis and melanogenesis Development (Supplement) 125-137

Bokhout BA, Van Gaalen C and Van der Heijden PJ (1981) A selected waterin-oil emulsion: composition and usefulness as an immunological adjuvant Veterinary Immunology and Immunopathology 2491-500

Braw-Tal R, Tisdall DJ, Hudson NL, Smith P and McNatty KP (1994) Follistatin but not $\alpha$ or $\beta A$ inhibin subunit mRNA is expressed in ovine fetal ovaries in late gestation Journal of Molecular Endocrinology 13 1-9

Byskov AG (1986) Differentiation of mammalian embryonic gonad Physiological Reviews 66 71- 117

Byskov AG and Lintern-Moore S (1973) Follicle formation in the immature mouse ovary: the role of the rete ovarii Journal of Anatomy 116 207-217

Carson WE, Haldar S, Baiocchi RA, Croce CM and Calgiuri MA (1994) The c-kit ligand suppresses apoptosis of human natural killer cells through the upregulation of bcl-2 Proceedings National Academy of Sciences USA 91 7553-7557

Clark DE, Tisdall DJ, Fidler AE and McNatty KP (1996) Localization of c-kit mRNA during the initiation of ovarian folliculogenesis in ovine fetal ovaries Journal of Reproduction and Fertility 106 329-335

Davies J and Davies DV (1950) The development of the mesonephros of the sheep Proceedings of the Zoological Society 120 73-93

Eddy EM, Clark JM, Gong D and Fenderson BA (1981) Origin and migration of primordial germ cells in mammals Gamete Research 4333-362

Fleischman RA (1993) From white spots to stem cells: the role of the kit receptor in mammalian development Trends in Genetics $9285-289$

Furichi T, Masuko K, Nishimune Y, Obinata M and Matsui Y (1996) Inhibition of testicular germ cell apoptosis and differentiation in mice misexpressing Bcl-2 in spermatogonia Development 122 1703-1709

Ismail RS, Dube M and Vnaderhyden BC (1997) Hormonally regulated expression and alternative splicing of kit ligand may regulate kit-induced inhibition of meiosis in rat oocytes Developmental Biology 184 333-343

Keshet E, Lyman SD, Williams DE, Anderson DM, Jenkins NA, Copeland NG and Parada LF (1991) Embryonic RNA expression patterns of the c-kit receptor and its cogate ligand suggest multiple functional roles in mouse development EMBO Journal 10 2425-2435

Liesveld JL, Harbol AW and Abboud CN (1996) Stem cell factor and stromal cell co-culture prevent apoptosis in a subculture of the megakaryoblsatic cell line, UT-7 Leukemia Research 20 591-600

McNatty KP, Smith P, Hudson NL, Heath DA, Tisdall DJ, O W-S and Braw-Tal R (1995) Development of the sheep ovary during fetal and early neonatal life and the effect of fecundity genes Journal of Reproduction and Fertility Supplement 49 123-135 
Manova K and Bachvarova RF (1991) Expression of c-kit encoded at the W locus of mice in developing embryonic germ cells and presumptive melanoblasts Developmental Biology 146 312-324

Manova K, Nocka K, Besmer P and Bachvarova RF (1990) Gonadal expression of c-kit encoded at the W locus of the mouse Development 110 1057-1069

Manova K, Huang EJ, Angeles M, De Leon V, Sanchez S, Pronovost SM, Besmer P and Bachvarova RF (1993) The expression pattern of the c-kit ligand in gonads of mice supports a role for the c-kit receptor in oocyte growth and in proliferation of spermatogonia Developmental Biology 157 85-99

Matsui Y, Zsebo KM and Hogan BLM (1990) Embryonic expression of a haematopoietic growth factor encoded by the $S l$ locus and the ligand for c-kit Nature 347 667-669

Mikori YA, Oh CK and Metcalfe DD (1995) The role of c-kit and its ligand, stem cell factor, in mast cell apoptosis International Archives of Allergy and Immunology 107 136-138

Neumann C and Cohen S (1997) Morphogens and pattern formation Bioessays $19721-729$

Orr-Urtreger A, Avivi A Zimmer Y, Givol D, Yarden Y and Lonai P (1990) Developmental expression of c-kit, a proto-oncogene encoded by the $W$ locus Development 109 911-923

Orth JM, Qiu J, Jester WF Jr and Pilder S (1997) Expression of the c-kit gene is critical for migration of neonatal rat gonocytes in vitro. Biology of Reproduction 57 676-683

Packer AI, Hsu YC, Besmer P and Bachvarova RF (1994) The ligand of the c-kit receptor promotes oocyte growth Developmental Biology 161 194-205

Payen EJ and Cotinot CY (1994) Sequence evolution of the SRY gene within Bovidae family Mammalian Genome 5(11) 723-725

Pesce M, Farrace MG, Piarentini M, Dolci S and De Felici M (1993) Stem cell factor and leukemia inhibitory factor promote primordial germ cell survival by suppressing programmed cell death (apoptosis) Development 118 1089-1094

Ratts VS, Flaws JA, Kolp R, Sorenson CM and Tilly JL (1995) Ablation of bcl2 gene expression decreases the numbers of oocytes and primordial follicles established in the postnatal female mouse gonad Endocrinology 136 $3665-3668$

Rodriguez I, Ody C, Araki K, Garcia I and Vassalli P (1997) An early and massive wave of germinal cell apoptosis is required for the development of functional spermatogenesis EMBO Journal 16 2262-2270

Sarkar FH, Li Y-W and Crissman JD (1993) A method for PCR sequencing of the p53 gene from a single $10 \mu \mathrm{m}$ frozen or paraffin-embedded tissue section BioTechniques 15(1) 36-38

Smith P, O W-S, Hudson NL, Shaw L, Heath DA, Condell L, Phillips DJ and McNatty KP (1993) Effects of the Booroola gene $\left(\mathrm{Fec} \mathrm{B}^{\mathrm{B}}\right)$ on body weight, ovarian development and hormone concentrations during fetal life journal of Reproduction and Fertility 98 41-54

Tanikawa M, Herada T, Mitsunari M, Onohara V, Iwabe T and Terakawa N (1998) Expression of c-kit messenger ribonucleic acid in human oocyte and presence of soluble c-kit in follicular fluid Journal of Clinical Endocrinology and Metabolism 83 1239-1242

Tilly JL (1996) Apoptosis and ovarian function Reviews in Reproduction 1 162-172

Tisdall DJ, Hudson N, Smith P and McNatty KP (1994) Localization of ovine follistatin and $\alpha$ and $\beta$ inhibin mRNA in the sheep ovary during the oestrous cycle journal of Molecular Endocrinology 12 181-193

Tisdall DJ, Quirke LD and Galloway SM (1996) Ovine stem cell factor gene is located within a syntenic group on chromosome 3 conserved across mammalian species Mammalian Genome 7 472-473

Tisdall DJ, Quirke LD, Smith P and McNatty KP (1997) Expression of the ovine stem cell factor gene during folliculogenesis in late fetal and adult ovaries journal of Molecular Endocrinology 18 127-135

Zamboni L and Upadhyay S (1982) The contribution of the mesonephros to the development of the sheep fetal testis American Journal of Anatomy 165 $339-356$

Zamboni L, Bezard J and Mauleon P (1979) The role of the mesonephros in the development of the sheep fetal ovary Annales de Biologie Animale Biochemie et Biophysics 19 1153-1178 